\section{Cemento-ossifying Fibroma of the mandible: A case report with 2 - year follow-up}

\section{Mandibulada Semento-Ossifiye Fibroma: 2 yıl takipli bir olgu raporu}

\author{
Assist. Prof. Tayfun Civak \\ Istanbul Yeni Yuzyıl University, Faculty of Dentistry, \\ Department of Oral and Maxillofacial Surgery, Istanbul
} Orcid ID: 0000-0002-8770-3731

Assoc. Prof. Faysal Uğurlu

Marmara University, Faculty of Dentistry,

Department of Oral and Maxillofacial Surgery, Istanbul

Orcid ID: 0000-0002-6509-2298

Received: 12 April 2018

Accepted: 16 October 2018

doi: 10.5505/yeditepe.2019.28291

Corresponding author:

Assist. Prof. Tayfun Civak

Binektaşı Street, No:10 Beyoğlu / Istanbul-Turkey

Phone: +905052413452

E-mail: tyfncvk@hotmail.com

\section{SUMMARY}

Cemento-ossifying fibroma is a benign fibro-osseous lesion in which normal bone is replaced by fibrous tissue containing variable amounts of mineralized material. $\mathrm{Pa}$ tients in the 3rd to 4th decades are most affected, with a high female-to-male ratio. The lesion can attain a huge size that commonly presents as a progressively growing behaviour if left untreated. Ossifying fibromas require more extensive treatment than other fibro-osseous lesions, such as fibrous dysplasias and osseous dysplasias, because they are true neoplasms. This paper reports a case of a cemento-ossifying fibroma, together with the clinical, radiological, and histopathological features, surgical treatment, and findings at the 2-year follow-up.

Keywords: Cemento-ossifying fibroma, benign tumor, mandible

\section{ÖZET}

Semento-ossifiye fibrom; normal kemiğin çeşitli miktarlarda mineralize materyal ihtiva eden fibröz doku ile yer değiştirdiği iyi huylu fibro-osseöz bir lezyondur. Yaşamın sıklıkla 3. ve 4. dekadında etkilenen hastalarda kadınlar erkeklere oranla daha fazla etkilenmektedir. Lezyon eğer tedavi edilmezse genellikle giderek büyüyen bir davranış ortaya koyar ve oldukça geniş boyutlara ulaşabilir. Ossifiye fibromlar, gerçek birer neoplazm oldukları için fibröz displaziler ve osseöz displaziler gibi diğer fibro-osseöz lezyonlara göre daha kapsamlı tedavi gerektirirler. Bu makalede klinik, radyolojik bulguları, histopatolojik özellikleri, cerrahi tedavisi ile birlikte 2 yıl takipli bir semento-ossiyife fibrom olgusu sunulmuştur.

Anahtar kelimeler: Semento-ossifiye fibroma, benign tümör, mandibula

\section{INTRODUCTION}

Cemento-ossifying fibroma (COF) was first described by Menzel in 1872 as a variant of ossifying fibroma. ${ }^{1}$ According to the latest WHO classification, COF is a separate entity characterized by the presence of fibrous tissue and a mineralized component that may comprise woven bone, lamellar bone, or cementum-like material. ${ }^{2}$ Although the lesion is thought to originate from the periodontal membrane, this is controversial due to the low-frequency involvement of extragnathic bones. ${ }^{3}$ An association with chromosomal abnormalities has also been identified. ${ }^{4}$ The most common localization of the lesion is the mandibular premolar-molar area. COF can be seen at any age but is diagnosed most frequently in the third and fourth decades of life. It occurs more frequently in females, and shows no predilection for a particular ethnicity. ${ }^{5}$ While small lesions are generally asymptomatic and detected incidentally, larger ones may cause facial deformity, malocclusion, and pain, depending on nerve involvement. Also, it may result in cosmetic and functional morbidity. ${ }^{6}$ 
Radiological appearance is characteristically well-demarcated radiolucency with variable radio-opacities, and it is frequently unassociated with teeth.?

\section{CASE REPORT}

A 52-year-old female, in whom a huge lesion was detected on panoramic radiograph taken for routine dental procedures, was referred to the Oral and Maxillofacial Surgery Department. The patient had no remarkable medical history and was clinically asymptomatic. The panoramic radiograph showed a well-demarcated mixed lesion extending from the left first premolar to the right first premolar. Intense radiopaque areas within the lesion resembled odontoma due to their tooth-like density. On CBCT, a lesion of $5 \times 4 \times 3 \mathrm{~cm}$ and both buccal and lingual cortical expansion were observed (Figure 1,2).

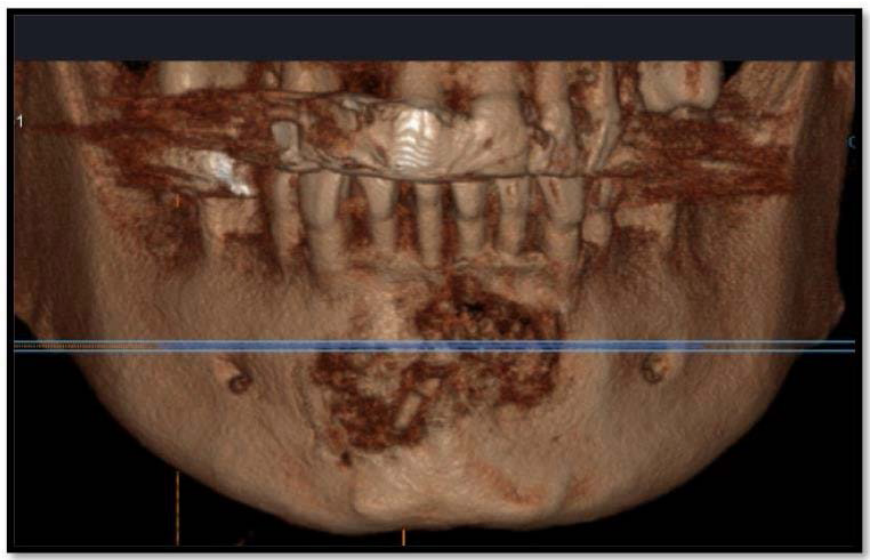

Figure 1. 3-D View

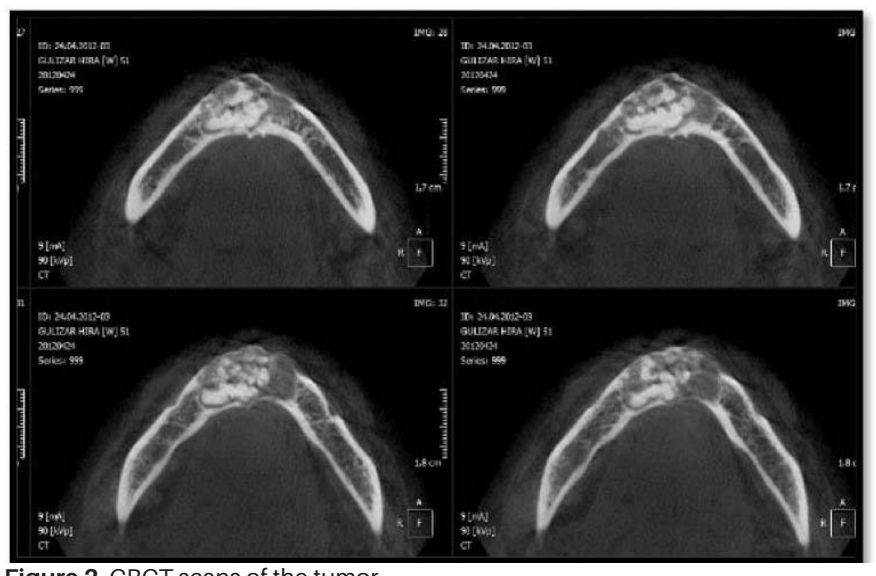

Figure 2. CBCT scans of the tumor

All teeth associated with the lesion were vital. The results of preoperative laboratory tests, including complete blood count, electrolyte levels, kidney and liver functions, alkaline phosphatase, and thyroid and parathyroid hormones, were normal. Based on these findings, the lesion was thought to be a fibro-osseous neoplasm, ossifying fibroma, or calcifying epithelial odontogenic tumor, and an excisional biopsy of the mass was performed. Immediately before the operation, endodontic treatment was performed on all teeth associated with the lesion. Under i.v. sedation and local anesthetic blockade, surgical excision was performed, and the solid bone around the lesion was subjected to aggressive curettage. Central incisors were extracted due to a lack of bone support, and apiectomy was performed on the other teeth. The wound was closed primarily using sutures (Figure 3, 4 and 5).

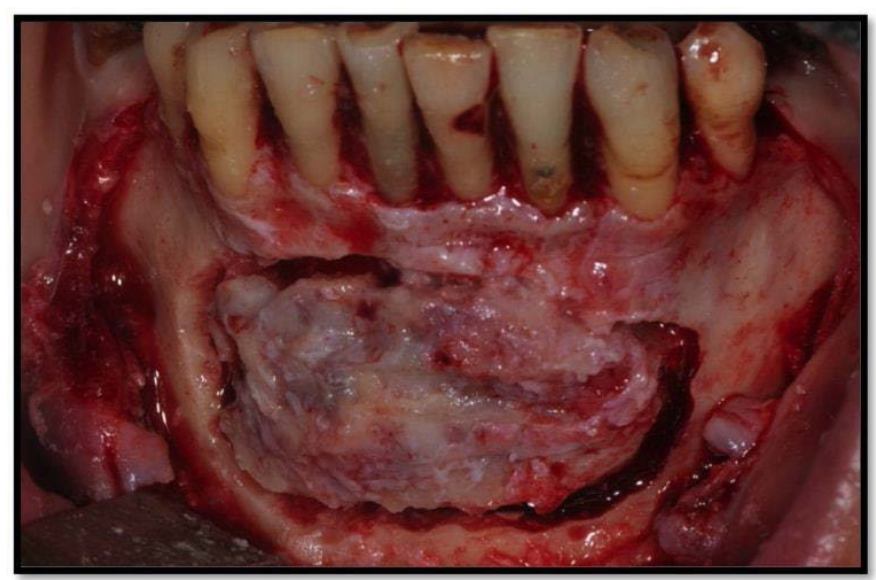

Figure 3. Osteotomy lines

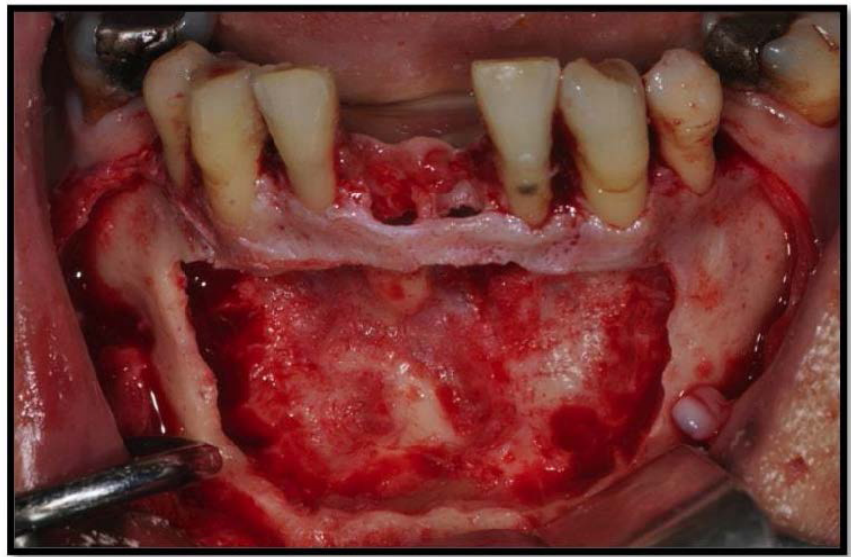

Figure 4. After removing the mass

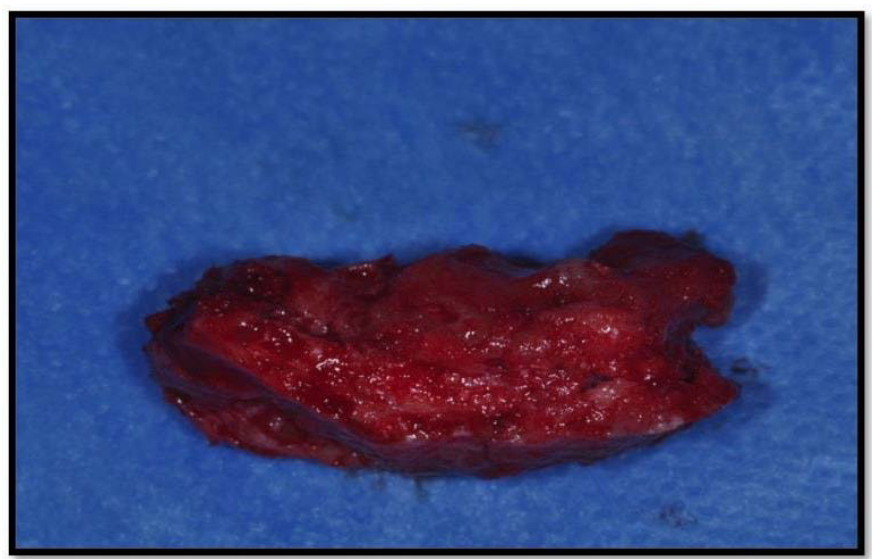

Figure 5. Specimen

The histopathological evaluation of the specimen revealed new bone formation and concentric cement islands located in a dense fibrous tissue comprising young mesenchymal cells. These cells formed short bundles and storiform structures. They had undergone differentiation to osteoblasts and cementoblasts to produce new bone trabeculae and concentric cement foci simultaneously (Figure 6,7). 


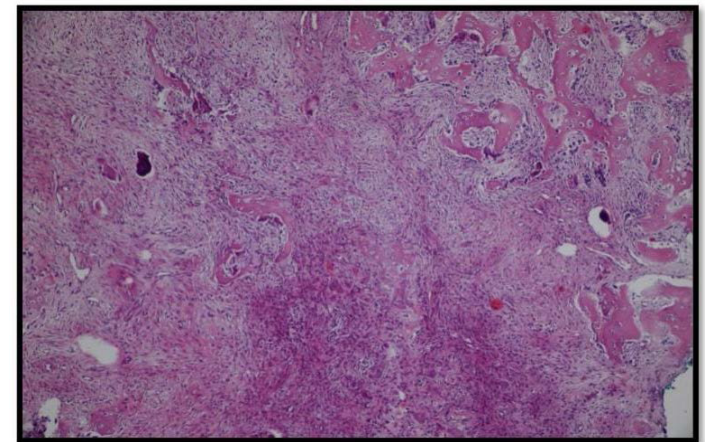

Figure 6. Histopathological appearance of semento-ossifying fibroma (SOF) reveals new bone formation and sement islands in a dense fibrous tissue (Hematoxylene \& Eosine, x100)

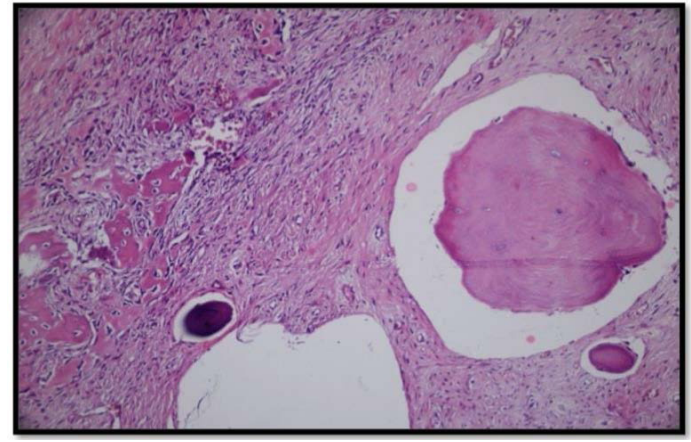

Figure 7. Small and larger concentric cement foci and new bone trabeculae in a fibroblastic tissue are observed microscopically in SOF (Hematoxylene \& Eosine, $\mathrm{x} 200)$

Postoperative follow up for 2 years was uneventful. The patient is symptom-free clinically, and radiological examinations every 6-months show bone formation with no recurrence. The bone defect has been completely filled, and the follow up is ongoing (Figure 8).

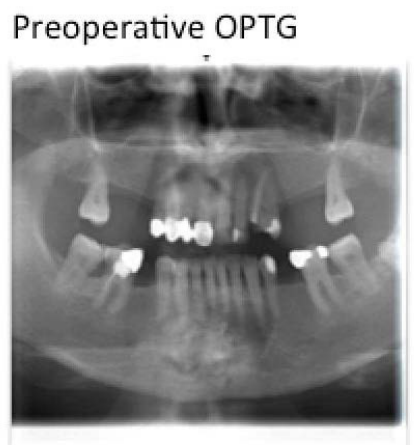

Postoperative 12.month

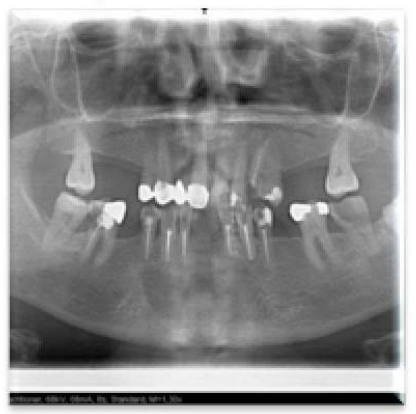

Figure 8. Follow-up OPTG's

\section{DISCUSSION}

COF is classified as a benign osteogenic tumor; however, the origin of the tumor remains a matter of debate. The majority of researchers believe that it arises from the periodontal ligament, which includes multipotent cells that can differentiate to cementum, lamellar bone, and fibrous tissue. ${ }^{8}$ If this is so, COF should occur only in the jawbones. However, case reports involving other craniofacial structures and long bones that do not contain periodontal ligament have described histopathological features similar to those of COF. ${ }^{9}$ Almost all of these reports involved craniofacial localization, including the paranasal sinuses, orbital cavity, frontal bone, and structures at the base of the skull, together with maxillary involvement. Additionally, cementum is of mesenchymal origin (as is bone), and cementum-like structures may be related not only to cementogenesis but also to membranous bone formation

Trauma is thought to be a cause of COF. Most previously reported COF cases had a history of trauma to the affected area. ${ }^{10}$ This indicates that the tumor may be of a reactive origin. In the present case, there was no known history of trauma or dental microtrauma.

COF is associated with chromosomal abnormalities. ${ }^{11} \mathrm{Pi}$ menta et al. reported three mutations in the HRPT2 gene in two cases of COF. ${ }^{12}$ Mutations in the HRPT2 gene are found in hyperparathyroidism-jaw tumor familial cancer syndrome, in which patients have ossifying fibroma of the jaws. ${ }^{9}$ The genetic study by Dal Cin et al. reported a case of mandibular COF with an interstitial deletion on chromosome 2 between q31-32 and q35-36. ${ }^{4}$ Silva et al. reported three COF cases in two patients who were brothers, and their findings support a familial and chromosomal abnormality etiology. ${ }^{13}$ Most genetic analyses of COF have focused on mutations in GNAS following its identification as the cause of fibrous dysplasia. Patel et al. analyzed GNAS mutations in cemento-ossifying fibromas and cemento-osseous dysplasias of the jaws and reported that mutations at the Arg201 codon of the GNAS gene were not present in any of the COD and COF cases examined. ${ }^{14}$ Shi et al. collected DNA samples from 30 fibrous dysplasia and 21 ossifying fibroma patients, and analyzed GNAS mutations. No mutations were found in any of the ossifying fibroma cases. ${ }^{15}$

Definitive diagnosis of cemento-ossifying fibroma requires correlation of the clinical, radiographic, and histopathological features due to its remarkable similarity to other fibro-osseous lesions, such as fibrous dysplasia and osseous dysplasias. Osseous dysplasias are generally associated with the root of a tooth, whereas COFs are usually unassociated with the tooth itself. Osseous dysplasias do not cause expansion of bone and show diffuse spread, in contrast to COF. COF shows well-demarcated radiolucency with variable opacity and expansion of bone. Fibrous dysplasia has a diffuse ground-glass appearance that merges with normal bone and is frequently associated with loss of the lamina dura, in contrast to COF. ${ }^{1,5,7}$ 
The treatment of choice for COF is conservative surgery due to the sharply circumscribed mass, which is easily separated from healthy bone, low vascularization, and slow growth. If untreated, the growing lesion can threaten vital structures, which may necessitate more aggressive treatment. ${ }^{16}$ Radiotherapy has no role in treatment because the tumor is radioresistant, and the post-radiation complications outweigh any benefit derived from radiotherapy. ${ }^{17}$ COF shows a low recurrence rate even with enucleation and curettage1. Recurrence is usually associated with inadequate surgical removal, and for this reason, long-term follow up of patients is important. Although this tumor does not undergo malignant transformation, Lee et al. reported a case of low-grade osteosarcoma arising from a cemento-ossifying fibroma. ${ }^{18}$ This highlights the importance of postoperative follow-up and opens a new field of discussion regarding surgery for this tumor.

\section{REFERENCES}

1. Kaushik SK, Shashidevi H, Nitesh N. Cemento-ossifying fibroma of the mandible: a benign but potentially destructive tumor. Oral and Maxillofacial Pathology Journal 2015; 6: 561-564.

2. Barnes L, Everson J, Reichart P, Sidransky D. World Health Organisation Classification. Pathology and Genetics of Head and Neck Tumours. Lyon: IARC Press, 2005: 319-320.

3. Young N, Rowson JE. Cementifying fibroma of the frontal bone: a case report. British Journal of Oral and Maxillofacial Surgery 2007; 45: 667-669.

4. Dal Cin P, Sciot R, Fossion E, Van Damme B, Van den Berghe $\mathrm{H}$. Chromosome abnormalities in cementifying fibroma. Cancer Genet Cytogenet 1993; 71: 170-172.

5. Nour Z, Paul MS, Lisette M. Ossifying fibromas of the jaws and craniofacial bones. Diagnostic Histopathology. 2015; 21: 351-358.

6. Eversole LR, Leider AS, Nelson K. Ossifying fibroma: a clinicopathologic study of sixty-four cases. Oral Surg Oral Med Oral Pathol. 1985; 60: 505-511.

7. Thompson, Lester DR. Head and Neck Pathology second edition. 2014: 351-355.

8. Eversole R, Su L, El Mofty S. Benign fibro-osseous lesions of the craniofacial complex: A review. Head and Neck Pathology 2008; 2: 177-202.

9. Gopinath D, Beena VT, Sugirtharaj G, Vidhyadharan K, Salmanul Faris K, Kumar SJ. Cemento-ossifying fibroma in a patient with end-stage renal disease. Case Reports in Dentistry 2013: 1-4.

10. Rangila R, Anita S, Parul S. Cemento-ossifying fibroma. Contemp Clin Dent. 2012; 3:83-85.

11. Gollin SM, Storto PD, Malone PS, Washington JA, Chidambaram A, Barnes $L$ et al. Cytogenetic abnormalities in an ossifying fibroma from a patient with bilateral reti- noblastoma. Genes Chromosomes Cancer 1992; 4: $146-$ 152.

12. Pimenta FJ, Gontijo Silveira LF, Tavares GC, Silva AC, Perdigao PF, Castro WH et. al. HRPT2 gene alterations in ossifying fibroma of the jaws. Oral Oncol 2006; 42: 735739.

13. P. Herbozo Silva, C. Mayer Olivares, I. Vargas Farren. Cemento-ossifying fibroma: clinical, radiological and histological analysis of 3 cases in one family. International Journal of Oral and Maxillofacial Surgery 2011; 40: 1182. 14. Patel MM, Wilkey JF, Abdelsayed R, D'Silva NJ, Malchoff C, Mallya SM. Analysis of GNAS mutations in cemento-ossifying fibromas and cemento-osseous dysplasias of the jaws. Oral Surg Oral Med Oral Pathol Oral Radiol Endod. 2010; 109: 739-743.

15. Shi RR, Li XF, Zhang R, Chen Y, Li TJ. GNAS mutational analysis in differentiating fibrous dysplasia and ossifying fibroma of the jaw. Mod. Pathol. 2013; 26: 1023-1031. 16. Naik RM, Guruprasad $Y$, Sujatha $D$, Gurudath $S$, Pai $A$, Suresh K. J . Giant cemento-ossifying fibroma of the mandible. Nat Sci Biol Med 2014; 5:190-194.

17. MacDonald-Jankowski DS, Li TK. Ossifying fibroma in a Hong Kong community: clinical and radiological features and outcomes of treatment. Dentomaxillofacial Rad. 2009; 38: 514-23.

18. Lee YB, Kim NK, Kim JY, Kim HJ. Low-grade osteosarcoma arising from cemento-ossifying fibroma: a case report. J Korean Assoc Oral Maxillofac Surg 2015; 41: 4851. 